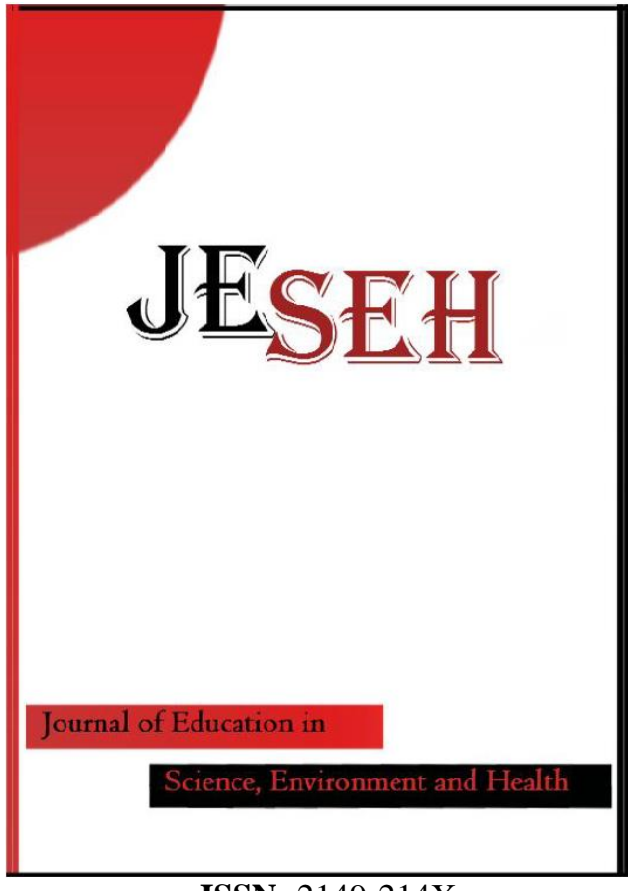

ISSN: $2149-214 \mathrm{X}$
Journal of Education in Science, Environment and Health

www.jeseh.net

The Effect of the Augmented Reality Applications in Science Class on Students' Cognitive and Affective Learning

Fatih Serdar Yildirim

${ }^{1}$ Akdeniz University

To cite this article:

Yildirim, F.S. (2020). The effect of the augmented reality applications in science class on students' cognitive and affective learning. Journal of Education in Science, Environment and Health (JESEH), 6(4), 259-267. DOI:10.21891/jeseh.751023

This article may be used for research, teaching, and private study purposes.

Any substantial or systematic reproduction, redistribution, reselling, loan, sub-licensing, systematic supply, or distribution in any form to anyone is expressly forbidden.

Authors alone are responsible for the contents of their articles. The journal owns the copyright of the articles.

The publisher shall not be liable for any loss, actions, claims, proceedings, demand, or costs or damages whatsoever or howsoever caused arising directly or indirectly in connection with or arising out of the use of the research material. 


\title{
The Effect of the Augmented Reality Applications in Science Class on Students' Cognitive and Affective Learning
}

\author{
Fatih Serdar Yildirim
}

\begin{tabular}{|c|c|}
\hline Article Info & Abstract \\
\hline Article History & \multirow{7}{*}{$\begin{array}{l}\text { This study aims to determine how effective science teaching with augmented } \\
\text { reality-based teaching material (science cards) is compared to the science } \\
\text { curriculum prescribed methods on students' academic achievement and their } \\
\text { views on augmented reality application. As a study group, } 63 \text { students who were } \\
\text { studying in a 7th grade in a secondary school in Antalya in the } 2019-2020 \\
\text { academic years were selected. Mixed research design was used in the research. } \\
\text { In the quantitative side of the research, the control group and the experimental } \\
\text { group who are taught using the augmented reality (science cards) were compared } \\
\text { in terms of achievement. In the qualitative side on the other hand, interview and } \\
\text { observation data were used. The results of the research have shown that while } \\
\text { Augmented Reality (AR) applications increase students' achievement, contribute } \\
\text { to the meaningful learning of abstract subjects, AR applications also increase the } \\
\text { students' interest and motivation towards science lesson. }\end{array}$} \\
\hline $\begin{array}{l}\text { Received: } \\
\text { 10 January } 2020\end{array}$ & \\
\hline $\begin{array}{l}\text { Accepted: } \\
01 \text { August } 2020\end{array}$ & \\
\hline Keywords & \\
\hline Augmented reality & \\
\hline & \\
\hline STEM education & \\
\hline
\end{tabular}

\section{Introduction}

Augmented Reality, or AR for short, is a form of real-time and interactive experience created by enriching realworld environmental elements using data such as computer-generated graphics, video, GPS, etc. A brand new type of experience is created by the adding of virtual images and graphics to real world images without leaving reality but instead, enriching it with the help of various software and hardware. In augmented reality applications, it is aimed to give the individual a virtual experience as if it were real in physical environment and in real time. A new environment is created by placing various virtual objects on the snapshot of the environment where the individual is located. The real environment is enriched by images, sounds, graphics and GPS data created in digital environment. This method can even be used to make the individuals in the environment be able to talk to objects (Aslan, 2017). The image created with augmented reality basically has three features. These features are as follows; merging of the real world with the virtual image, real time interaction of real and virtual objects and location of the image obtained in the three dimensional environment (Azuma, 1997; Wu, Lee, Chang, \& Liang, 2013). Augmented reality provides information that is not normally detectable by the senses and cognitive process of humans to strengthen and enrich the reality (Azuma, 1999). Augmented reality, in its simplest definition, is "presenting computer produced digital objects together with real objects" (Uluyol \& Eryilmaz, 2014). Learning environments supported by augmented reality, allow students to see 2D objects in 3D and to examine these objects from various perspectives, and to learn by doing-living. (Arvanitis, Petrou, Knight, Savas, Sotiriou, Gargalakos, \& Gialouri , 2007; Wu, Lee, Chang, \& Liang, 2013). AR technology attracts educators' attention with its ability to interact with virtual and real objects, providing learning by living and increasing attention and motivation (Singhal, Bagga, Goyal, \& Saxena, 2012). Due to such advantages, studies on AR are increasing day by day.

In their study, Çetinkaya and Akçay (2013) discussed the concept of augmented reality, its use in education and application examples. İbili and Şahin (2013) stated that the augmented reality-supported geometry teaching using their 3D geometry book software they created helped improving students' cognitive and affective skills. The teachers who participated in the study stated that the application increased their thinking skills such as making assumptions, generalizing and drawing conclusions and positively affected their interests and motivations. Avcı and Taşdemir (2019) have designed a visual and educational virtual and augmented reality (mixed) game for the periodic table subject with the Unity 3D game engine. With the application, students learned the elements in the periodic table in an audible, visual and entertaining environment by experimenting as if they were in an experimental environment. On the other hand, thanks to the application, students who do not have a science laboratory in their schools have the opportunity to do activities. In addition, with the application, students experienced more impressive understanding processes in an interactive environment without being affected by the risks caused by the chemicals in the experimental environment. 
Analyzing the use of augmented reality in education, it is seen that these applications contribute positively to the academic performance of students (Abdüsselam \& Karal, 2012; Buluş Kırıkkaya, \& Şentürk 2019; Chen \& Wang, 2015; Farias \& Dantas, 2011; Patirupanusara, 2012), increase students' motivation for the class (Chiang, Yang, \& Hwang, 2014; Di Serio, Ibáñez, \& Kloos, 2012; İbili \& Şahin, 2013; Sırakaya \& Alsancak Sırakaya, 2018) and make the learning process remarkable and effective (Avc1 \& Taşdemir, 2019; Farias \& Dantas, 2011).

\section{The purpose and importance of the research}

In today's world, educational technologies are developing very rapidly and getting integrated into classroom environments. With each passing day, the interaction of students enrolling into the education system with technology increases compared to the previous generations. In order to meet the expectations of these students, their schools need to adapt to these technologies and meet the needs of the new generations. Traditional lessons, which are taught through the method of direct expression, weaken students' connection with the school and reduce their motivation. However, when the teaching process include course materials utilizing augmented reality technology, it is easier for students to obtain correct information, achieve better inferences and understand abstract concepts that are difficult to learn (Abdüsselam \& Karal, 2012).

In this research, in order to increase the value of students' learning and increase their interest and motivation towards science learning, AR application was implemented in the science class. Teaching a science subject with AR increases the importance of working in terms of science education. In this study, it is aimed for students to discover the structure and organelles of the cell in three dimensions by the augmented reality application. In line with this purpose, educational activities supported by AR technology (science cards) are designed for the subject of "Comparison of Plant and Animal Cells and Tasks of Cell Organelles" contained by the Cells and Divisions unit of the Science Class and it is aimed to reveal whether the AR technology increases the students motivation towards learning. For this purpose, the following questions are discussed:

1. Is there a significant difference between the pretest scores of the experimental group to which augmented reality (AR) method is applied and the control group where the science curriculum prescribed method is applied?

2. Is there a significant difference between the posttest scores of the experimental group to which the augmented reality (AR) method is applied and the control group to which the science curriculum prescribed method is applied?

3. What are the opinions of students in the experimental group about the application of augmented reality (AR) method?

\section{Method}

\section{Research Model}

This research was carried out with the mixed method. Mixed method research provides an alternative approach to the researcher in achieving the "depth and detail" where quantitative research methods lack and "generalization and prediction" where qualitative research methods lack (Yıldırım \& Şimşek, 2013). Mixed research allows researchers to use both qualitative and quantitative approaches / methods in a single study (Cresswell and PlanoClark, 2014). In this study; convergent parallel design, which converges from mixed research designs is used. Qualitative and quantitative data, which are equally important in this research design, are collected together and analyzed separately (Creswell, 2011). In the last step, similarities and differences between quantitative and qualitative findings are compared and interpreted. Thus, it is aimed to have better results (Creswell \& Piano Clark, 2011). In order to compare the academic achievement of the experimental group, in which the augmented reality (AR) application was applied in science education, and the preferred control group students of the science curriculum prescribed methods, an experimental with pretest-posttest control group was chosen.

Table 1. Pattern of the study

\begin{tabular}{llll}
\hline Group & Before Application & Method of Application & After Application \\
\hline Experimental & Pretest (Test1) & Augmented Reality & $\begin{array}{l}\text { Posttest (Test1) } \\
\text { Inteview }\end{array}$ \\
Control & Pretest (Test1) & $\begin{array}{l}\text { The science curriculum } \\
\text { prescribed methods }\end{array}$ & Posttest (Test1) \\
\hline
\end{tabular}


In order to support quantitative data, the opinions of students in the experimental group about the application were taken and the qualitative documents created during the application were used. The study group of the study consists of 7th grade students studying in a secondary school in Antalya in the 2019-2020 academic years. A total of 63 students, 31 in the experimental group and 32 in the control group, participated in the study. The groups were appointed through impartial selections.

Table 2. Number of students participating in the research

\begin{tabular}{llll}
\hline Group & Girls & Boys & Total \\
\hline Experimental Group & 16 & 15 & 31 \\
Control Group & 15 & 17 & 32 \\
Total & 31 & 32 & 63 \\
\hline
\end{tabular}

\section{Process of conducting experimental processes}

This research was carried out with 7th grade students in a secondary school in Antalya. After determining the subject to be used in the experimental process of the research (Structure of Plant and Animal Cell, Cell Organelles), the AR application to be used on the subject was determined and the material (Science Cards) to be used during Augmented Reality application was provided on the internet. Experimental group students were informed about the application before the application. The application was conducted on both the experimental and the control groups by the same teacher. Three prospective science teachers participated in the applications as observers. While the subjects in the experimental group were taught using AR-based material, the same subjects in the control group were taught in two dimensions based on textbooks. During the four-week unit, AR applications are used in appropriate times for the experimental group. Photographs taken during the augmented reality application to the experimental group are shown in Figure 1.

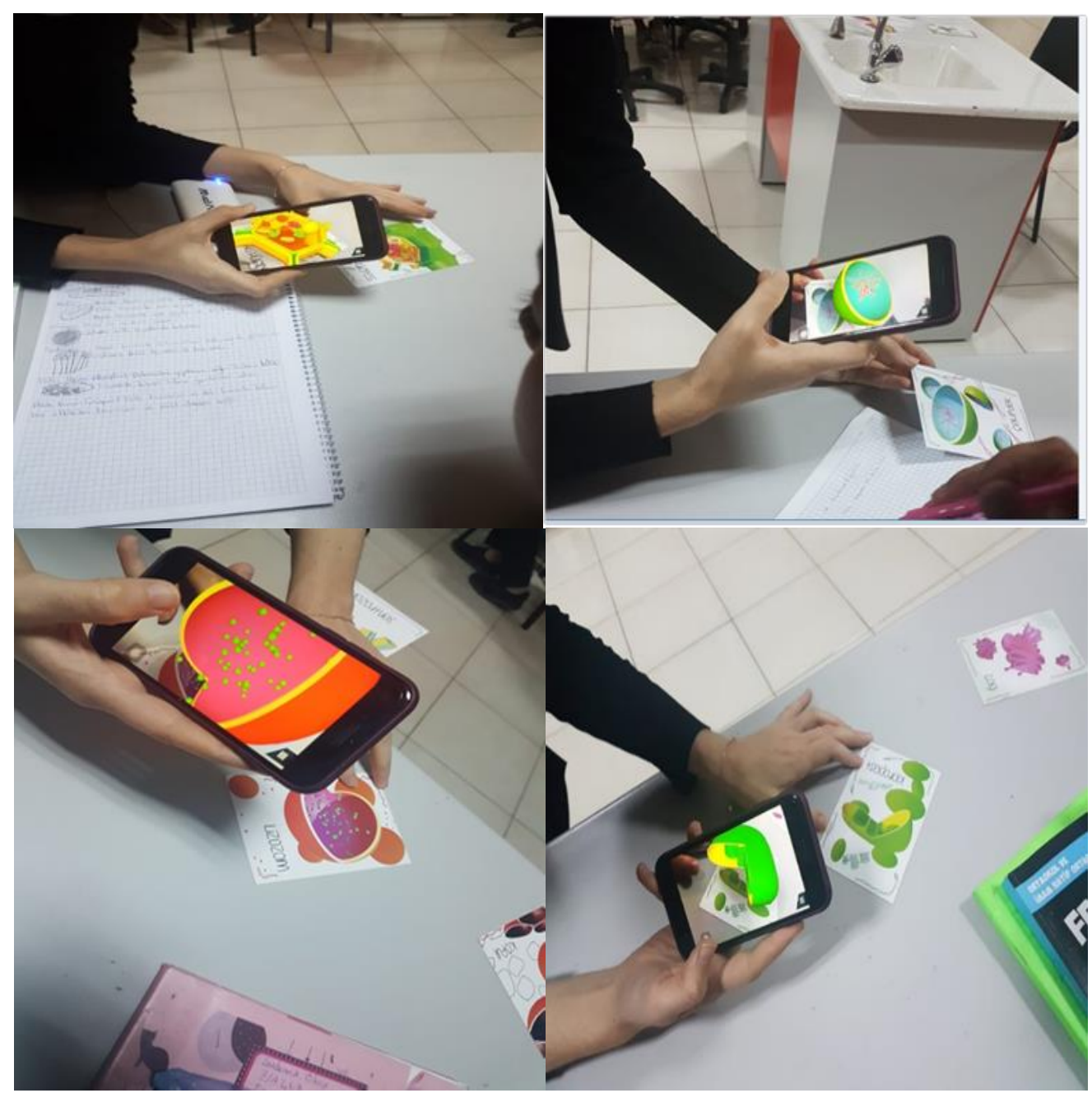

Figure 1. Examples of applications made by the experiment group students 


\section{Reliability and Validity of Data Collection Tools}

As data collection tools, an achievement test prepared for the science class, for "Cells and Divisions" unit, a semi-structured student interview form containing student views about the application and observer diaries were used.

Achievement Test: A multiple-choice test of 20 questions is prepared in order to be taken by the experimental and control groups to measure the achievements concerning the 7th grade unit of Cells and Divisions. The test was prepared to cover all the achievements of the unit. Thus, the content validity of the test was ensured. A total of seven experts, two science education academics and five experienced science teachers, were consulted on subjects such as whether the test was sufficient to measure the achievements of the unit, there was any errors and the questions were expressed clearly. The questions were revised in line with the opinions of the experts. The final version of the test was solved by two 7 th grade students and feedback was received from the students on whether they understood the questions. In line with the feedback received from the students regarding the final version of the test, very minor revisions were made and the test was finalized. The final version of the test was applied to an 8th grade student group of 200 students in another school. KR-20 reliability coefficient of the achievement test was measured to be 0.82 .

Interview Form: During the process of preparation of the student interview form, as a result of review of the relevant literature, open-ended questions were asked in order to get the opinions of the experimental group students. This prepared form was revised in line with the feedback received from 2 field experts. In order to determine whether the questions in the form were clearly understood, they were asked to two 7th grade students before taking their final forms. These questions were directed to the students in the experimental group.

Observation Form: An observation form that draws attention to the main points of the application has been prepared for prospective science teachers who go to schools for observation. Prospective teachers were asked to learn the concepts of the AR application by considering the items in this form, to observe the students' interest in the course and the main topics of the teacher's process of performing the AR application, and to write their observations in each lesson under the item in the form.

\section{Data Collection Process:}

Before the application started, an achievement test was prepared in accordance with the student levels and achievements. The prepared achievement test was applied to both experimental and control group students as a pretest before the research. After completing the lessons with the AR applications in the experimental group and with the science curriculum prescribed method for the control group, the achievement test prepared was applied as a post-test. In order to reinforce the quantitative data, while the opinions of the teacher and the experimental group students about AR application were taken, the observations of the teacher candidates were used during the process.

\section{Data Analysis}

Analysis of quantitative data

In this research, quantitative data were obtained with the achievement test prepared for the subject. The data of the research were analyzed with the t test.

\section{Analysis of qualitative data}

Descriptive analysis and content analysis techniques were used in the analysis of qualitative findings. For the qualitative data to be collected in descriptive analysis, the main framework was determined depending on the research problem, and after making the relevant inferences from the data, direct quotations from the interview and observation data were made. The inference made from the data collected during the descriptive analysis phase is reinforced with direct quotations. At the content analysis stage, the qualitative data collected were merged under certain categories. At this stage, the main themes determined based on the categories for qualitative analysis are included. Analyzes were made under these main themes, and were supported by quotations from the descriptive analysis (Yıldırım and Şimşek, 2013). 


\section{Findings}

In this section, quantitative and qualitative findings are given under separate topics.

\section{Quantitative Findings}

When Table3 is analyzed, it is seen that the average score of the students in the experimental group of the research is 36.12 as the control group students' is 34.06. The statistical significance of the difference between the mean scores of the groups was calculated with the independent $t$ test. In the pretest application of the achievement test of both groups, the difference between the scores of the groups were seemed not to be statistically significant ( $\mathrm{p}>0.05)$.

Table 3. Results of pretest mean scores of the groups with independent $t$ test

\begin{tabular}{llllll}
\hline Groups & $N$ & Mean & S.D. & $t$ & $p$ \\
\hline Experimental & 31 & 36.12 & 15.36 & \multirow{2}{*}{, 587} & \multirow{2}{*}{0.559} \\
Control & 32 & 34.06 & 12.47 & & \\
\hline
\end{tabular}

After the application, the academic achievement test was re-applied as a post-test to the control and experimental groups. Analysis results related to the post-test results of the groups are given in Table4. When Table4 is analyzed, it is seen that the average score of the students in the experimental group of the research is 77.41 as the control group students' is 64.21 . The statistical significance of the difference between the mean scores of the control and experimental groups was calculated with the independent $t$ test. In the posttest application of the achievement test of both experimental and control groups, the difference between the scores of the groups were seemed to be statistically significant and in favor of the experimental group ( $\mathrm{p}<0.05)$.

Table 4. Results of posttest mean scores of the groups with independent $\mathrm{t}$ test

\begin{tabular}{llllll}
\hline Groups & $N$ & Mean & S.D. & $t$ & $p$ \\
\hline Experimental & 31 & 77.41 & 21.71 & 2,131 & \multirow{2}{*}{0.037} \\
Control & 32 & 64.21 & 27.06 & & \\
\hline
\end{tabular}

\section{Qualitative findings}

After analyzing the qualitative data through content analysis, two main themes were determined. These themes are: the effect of augmented reality teaching material on the cognitive domain and the effect of augmented reality teaching material on the affective domain. These two main themes are categorized as:

1- Cognitive domain, and 2-Affective domain. Other sub-themes identified are presented in paragraphs within these main themes.

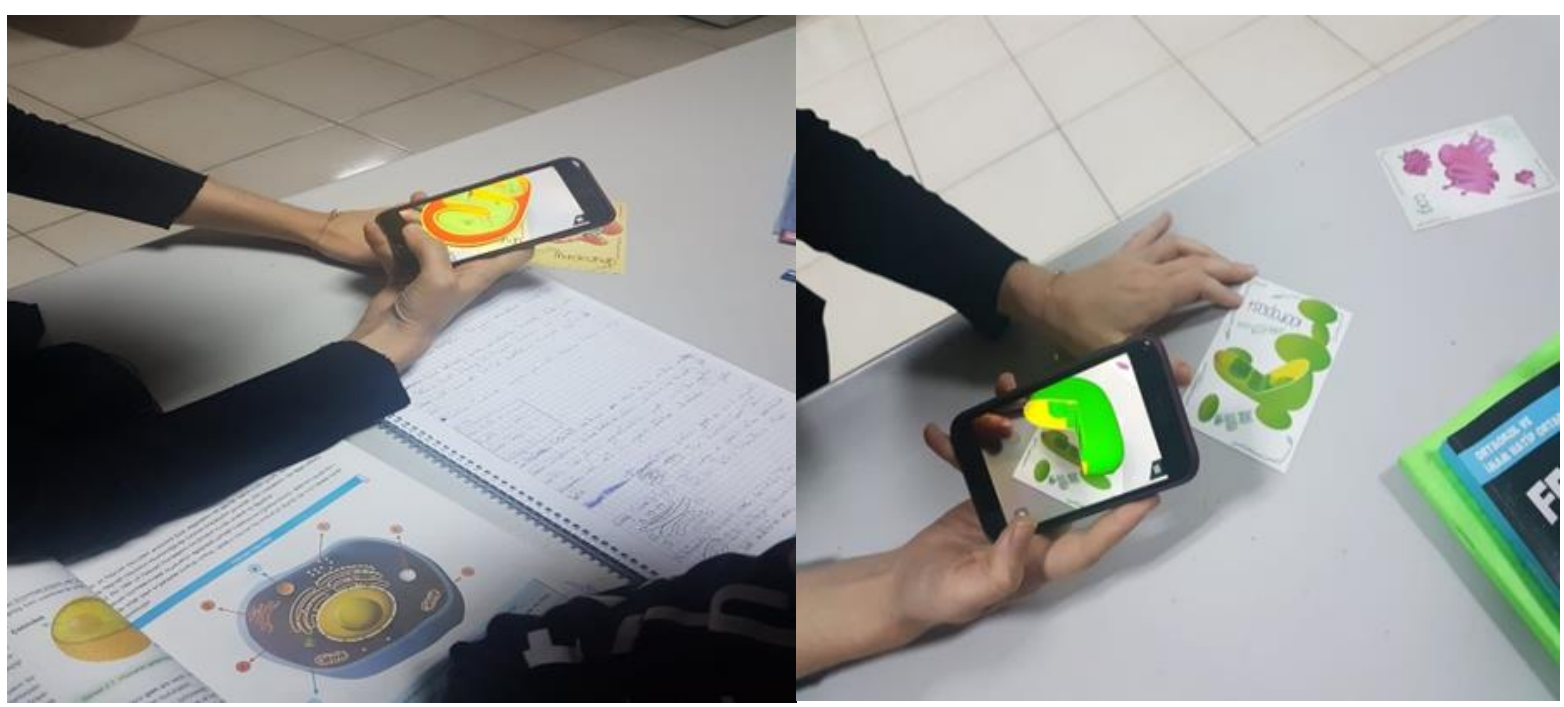

Figure 2. Examples of AR applications where two dimensional images appear in three dimensions 


\section{Cognitive Domain}

The Cognitive Domain theme contains findings that support the quantitative findings of the research. Findings of quantitative dimension show that AR application positively affects students' learning on the cognitive domain. The qualitative findings collected in the research also support this result. The data collected in this section demonstrates AR application; 1-objectifies abstract subjects, 2-provides meaningful learning.

\section{Abstract-Concrete}

Students included in the AR application had the opportunity to view the cell and its organelles that they had previously seen from the books in the two dimensional form in a three dimensional form using their cell phones. According to the development stages of Piaget, it is more convenient for the 7th grade students, who are at the border of the concrete and abstract processes, to comprehend the concrete learning more easily in accordance with their development levels. Seeing the cells and their organelles in three dimensions instead of two dimensions made it possible for students to see that an abstract concept has become concrete and made it easier to learn. Figure 2 shows students observing two dimensional drawings in a three dimensional form. Student A's opinion on this matter is as follows:

Student A: ...Seeing two dimensional pictures on the book, I had never thought about organelles positions within the cell. I thought I was supposed to learn them as they were shown in the book. But when I displayed the cards with my cellphone, I saw the organelles come to life. They could move in 3D just like they were real. Now I think I understand the organelles much better. I can still see their images as I saw them on my cell phone. They were beautiful.

The notes of Observer A on this subject also support this finding.

Observer A:...Students looked really excited when we moved on to the AR application previous week. It completely changed the vibe during the class. Everyone checked the cell and its organelles using their cell phones. Everyone checked all the cards one by one without the teacher having to tell them to do so. In this class, the teacher asked questions that measure whether cells and organelles are learned. Almost all of the students who spoke gave correct answers. There were students trying to describe and visualize organelles in a three dimensional form (09.10.2019).

\section{Meaningful learning}

It is seen that the students' participation in the learning activity with AR provides them to learn the abstract of cells and organelles, which is an abstract subject. Students have found themselves successful in solving questions about cells and organelles not only in post-test but also in other exams. They were able to adapt what they learned to other problematic situations. Student B's opinion on this matter is as follows:

Student B:...Seeing the three-dimensional image of organelles and examining them allowed me to do questions about organelle forms in exams easily.

Student C: ... I think I have learned the subject thoroughly. It was much better than reading from the book or just listening to the teacher talking about the subject.

Observation notes of Observer B also support these findings.

Observer B: ... After the implementation of AR, students were very successful in solving the end of unit tests. It is understood that the activity helped students learn meaningfully. Students can solve different tests. They can solve different questions based on what they have learned (10.10.2019).

\section{Affective Domain}

Augmented reality practices have increased the motivation of the students towards the lesson and caused them to be interested in the lesson. The views of students $\mathrm{A}, \mathrm{B}$ and $\mathrm{C}$ in this regard are given below. 


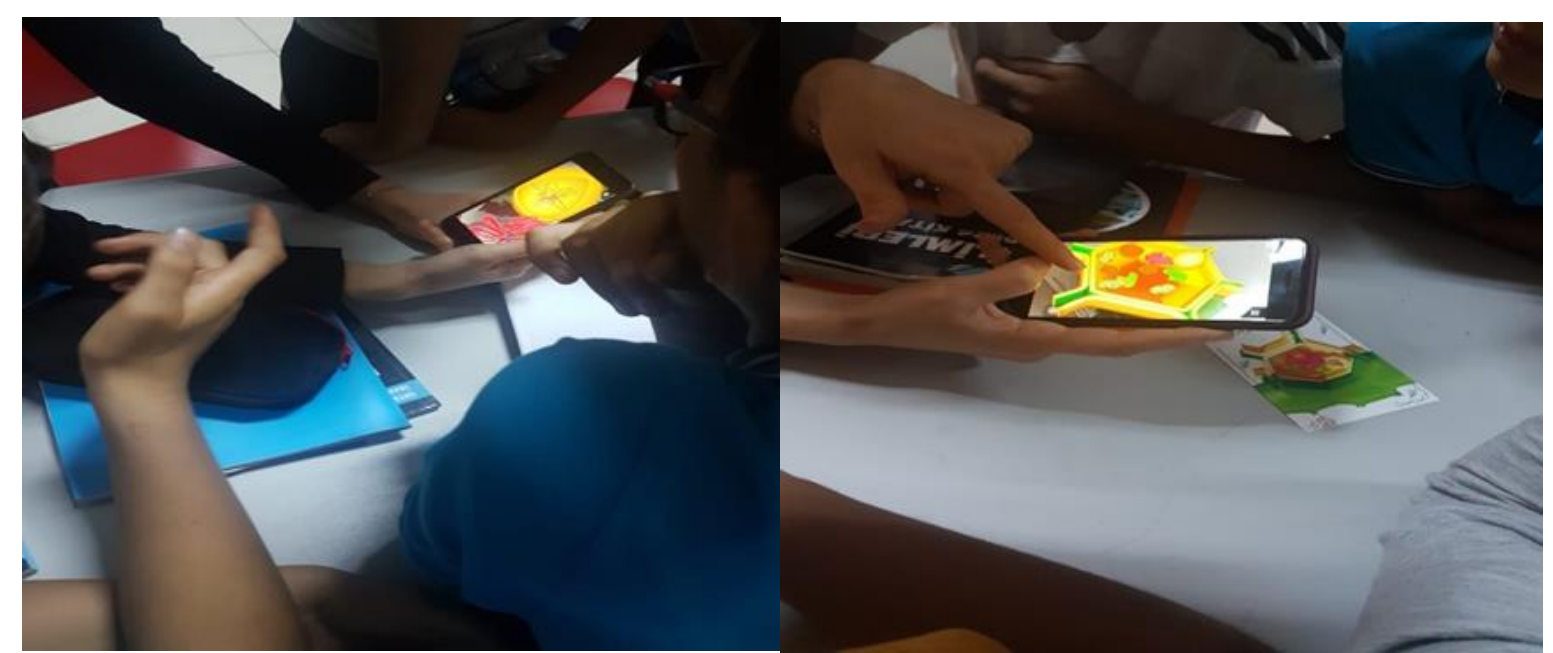

Figure 3. Examples showing students' interest in AR implementation

Student A:...I wish we used augmented reality applications in our new subjects, the lesson was very enjoyable.

Student B:... It was a nice activity, I had a lot of fun and followed the lessons without getting bored.

Student C: A remarkable and pleasant application that I have encountered for the first time. It helped me follow the lesson better.

Observation notes of Observers A and B also support these findings.

Observer A: ...Students seem very lively even before the teacher came to the class. They are excitedly waiting to use their phones. They are waiting for the class to start all motivated after experiencing the previous lesson (17.10.2019).

Observer B: ...Students are very happy during the course. The classroom is a bit noisy, obviously. Those who see the image on the phone are extremely happy $(23.10 .2019)$.

\section{Discussion}

In this research, it has been revealed that AR applications increase the academic achievement of students. This result of the study coincides with the conclusion that the augmented reality applications applied in the experimental group in teaching the subject of Solar System and beyond in the 7th grade science course of Kırıkkaya and Şentürk (2019) positively affect the academic success. It also coincides the results of studies conducted by Akçayır \& Akçayır (2017), Buluş, Kırıkkaya \& Şentürk (2019), Perez-Lopez \& Contero (2013), students gain better learning outcomes about the subject in the learning environment supported by AR applications.

In the study, it is observed that AR applications contribute to students learning by objectifying abstract subjects. Perez-Lopez and Contero (2013) stated that in their research with primary school students, augmented reality practices enable more effective learning compared to traditional environments in subjects of digestion and circulatory systems. The conclusion of Perez-Lopez and Contero (2013) is similar to the conclusion of this study that AR practices contribute to the meaningful learning of abstract subjects.

Another result revealed in the research is that AR applications increase students' interest and motivation towards science classes. In recent years, virtual and augmented reality practices are seen as effective course material used in learning environments (Akçayır \& Akçayır, 2017; Buluş, Kırıkkaya \& Şentürk, 2019; Billinghurst, 2002; Chiang, Yang \& Hwang, 2014; Korucu, Usta \& Yavuzaslan, 2016; Yalçın Çelik, 2019). Researches, similar to this research result, indicate that students are more willing, happy and excited during the lesson in learning environments supported by AR applications (Avc1 \& Taşdemir 2019; Chiang et al., 2014; Delello, 2014; Furió et al., 2015) and actively participate in the classes (Delello, 2014; Estapa abd Nadolyn, 2015; Gopalan, Zulkifli \& Bakar, 2016). 


\section{Conclusion and Recommendations}

When the quantitative and qualitative data of the research are combined, it is observed that AR application positively affects students' achievement. In addition to the statistical results, qualitative findings show that education with AG contributes to students learning abstract subjects even though they are in the concrete operations period. At the same time, students were able to adapt what they learned to other situations. This shows that students can learn an abstract subject meaningfully with AR. Another conclusion that can be drawn from the qualitative findings of the research is that AR application has increased students' interest and motivation towards the classes.

Considering the results obtained from the study, the suggestions to be given for future research can be sorted as follows; Moving from the result that AR has a positive effect on students' motivation to learn science, studies can be conducted to develop learning materials prepared with AR technology for science education. It is a good idea to encourage teachers for using such methods in order to make the AR technology more commonly-used. In-service trainings can be organized for teachers to prepare and use these applications. The results to be obtained by repeating this research conducted with secondary school students at different educational levels can be compared. Studies can be done on the effective planning of the integration of AG technology into the training process.

\section{Scientific Ethics Declaration}

The author(s) declare that the scientific ethical and legal responsibility of this article published in JESEH journal belongs to the author(s).

\section{References}

Abdüsselam, M. S. \& Karal, H. (2012). The effect of mixed reality environments on the students' academic achievement in physics education: 11th grade magnetısm topic example. Journal of Research in Education and Teaching, 1 (4), 170-181.

Akçayır, M. \& Akçayır, G. (2017). Advantages and challenges associated with augmented reality for education: A systematic review of the literature. Educational Research Review, 20, 1-11.

Aslan, R. (2017). International competitive new possibilities: Virtual reality, increased reality and hologram. Journal Detail, 5(49), 21-26.

Arvanitis, T. N., Petrou, A., Knight, J. F., Savas, S., Sotiriou, S., Gargalakos, M. and Gialouri, E. (2007). Human factors and qualitative pedagogical evaluation of a mobile augmented reality system for science education used by learners with physical disabilities. Personal and Ubiquitous Computing, 13(3), 243250

Avc1, A.F., Taşdemir. Ş. (2019). Periodic table teaching with augmented and virtual reality. Journal of SelcukTechnic. Volume 18, Number:2

Azuma, R. T. (1997). A survey of augmented reality. Presence: Teleoperators \& Virtual Environments, 6 (4), 355-385.

Azuma, R. T. (1999). The challenge of making augmented reality work outdoors. Mixed reality: Merging real and virtual worlds, 1, 379-390.

Billinghurst, M. (2002). Augmented reality in education. New Horizons for Learning, 12(5), 1-5.

Buluş Kırıkkaya, E., \& Şentürk, M. (2018). The impact of using augmented reality technology in the solar system and beyond unit on the academic achievement of the students. Kastamonu Education Journal, 26 (1), 181-189.

Chiang, T.-H.-C., Yang, S.-J.-H., \& Hwang, G.-J. (2014). An augmented reality-based mobile learning system to improve students' learning achievements and motivations in natural science inquiry activities. Educational Technology \& Society, 17 (4), 352-365.

Chen, C. \& Wang, C.-H. (2015). Employing augmented-reality-embedded instruction to disperse the imparities of individual differences in earth science learning. Journal of Science Education and Technology, 24(6), 835-847.

Çetinkaya, H. H. \& Akçay, M. (2013). Augmented reality applications in educational environments. Academic Informatics Conference, 23-25 Ocak 2013, Antalya: Akdeniz Üniversitesi.

Cresswell, J.W \& Plano Clark, V.L. (2014). Designing and conducting mixed methods research. Thousand Oaks, CA: Sage Publications, Inc. 
Delello, J. A. (2014). Insights from pre-service teachers using science-based augmented reality. Journal of Computers in Education, 1(4), 295-311.

Di Serio, Á., Ibáñez, M. B., \& Kloos, C. D. (2012). Impact of an augmented reality system on students' motivation for a visual art course. Computers \& Education, 68, 586-596.

Estapa, A., \& Nadolny, L. (2015). The effect of an augmented reality enhanced mathematics lesson on student achievement and motivation. Journal of STEM Education: Innovations and Research, 16(3), 40-48.

Farias, L., Dantas, R., \& Burlamaqui, A. (2011, September). Educ-AR: A tool for assist the creation of augmented reality content for education. In Virtual Environments Human-Computer Interfaces and Measurement Systems (VECIMS), 2011 IEEE International Conference on (pp. 1-5). IEEE.

Furió, D., Juan, M.-C., Segui, I. \& Vivó, R. (2015). Mobile learning vs. traditional classroom lessons: A comparative study. Journal of Computer Assisted Learning, 31(3), 189-201.

Gopalan, V., Zulkifli, A. N., \& Bakar, J. A. A. (2016). A study of students' motivation using the augmented reality science textbook. In F. A. A. Nifa, M. N. M. Nawi, \& A. Hussain (Eds.), Proceedings of AIP Conference, 1761(1), AIP Publishing.

İbili, E. \& Şahin, S. (2013). Software design and development of an interactive 3D geometry book using augmented reality:ARGE3D. Afyon Kocatepe University Journal of Science and Engineering, 1-8.

Karasar, N. (2016). Scientific research method: Concepts principles techniques. Ankara: Nobel Academic Publishing

Korucu, A.T., Usta, E. \& Yavuzaslan, İ.F. (2016). Using augmented reality in education: A content analysis of the studies in 2007-2016 period. Journal of Subject Teaching Research, 2(2), 84-95.

Patirupanusara, P. (2012). Marker-based augmented reality magic book for anatomical education. International Conference on Computer and Communication Technologies (ICCCT'2012), (s. 136-138). Phuket

Perez-Lopez, D. \& Contero, M. (2013). Delivering educational multimedia contents through an augmented reality application: A case study on its impact on knowledge acquisition and retention. Turkish Online Journal of Educational Technology - TOJET, 12(4), 19-28.

Sirakaya, M., \& Alsancak Sirakaya, M. (2018). The effect of augmented reality use in science education on attitude and motivation. Kastamonu Education Journal, 26(3), 887-896.

Singhal, S., Bagga, S., Goyal, P. \& Saxena, V. (2012). Augmented chemistry: Interactive education system. International Journal of Computer Applications, 49(15), 1-5.

Uluyol, Ç, \& Eryilmaz, S. (2014). Examining pre-service teachers' opinions regarding to augmented reality learning. GEFAD Gazi University Journal of Gazi Education Faculty, 34(3).

Wu, H.-K., Lee, S. W.-Y., Chang, H.-Y. \& Liang, J.-C. (2013). Current status, opportunities and challenges of augmented reality in education. Computers ve Education, 62, 41-49.

Yalçın Çelik, A. (2019). Preservice biology and chemistry teachers' experience of augmented reality materials. Karaelmas Journal of Educational Sciences 7 (2019) 123-132

Yıldız, Ş. \& Beşoluk, Ş. (2019). The investigation of the effect of problem based teaching approach on students' problem solving skills and academic achievements in science course, Journal of Individual Differences In Education, 1(1), 50-68.

Yıldırım, A. \& Şimşek, H. (2013). In social sciences qualitative research methods (9. printing). Ankara: Seçkin Publishing.

Wu, H.K., Lee, S. W. Y., Chang, H. Y. \& Liang, J. C. (2013). Current status, opportunities and challenges of augmented reality in education, Computers and Education, 62, 41-49.

\section{Fatih Serdar Yildirim}

\section{Author Information}

